Notice of Construction

Work in Tank Farm Waste

Transfer Pit 244-TX

Double-Contained

Receiver Tank

RECORD COPY

United States

Department of Energy

Richland, Washington 
s

\section{Notice of Construction Work in Tank Farm Waste Transfer Pit 244-TX Double-Contained Receiver Tank}

\section{RECORD COPY}




\section{RELEASE AUTHORIZATION}

Document

Number:
DOE/RL-99-47, Rev. 0

Notice of Construction Work in Tank Farm Waste

Transfer Pit 244-TX Double-Contained Receiver Tank
Document

Title:

This document, reviewed in accordance with DOE Order 241.1, "Scientific and Technical Information Management," and DOE G 241.1-1, "Guide to the Management of Scientific and Technical Information," does not contain classified or sensitive unclassified information and is:

\section{APPROVED FOR PUBLIC RELEASE}

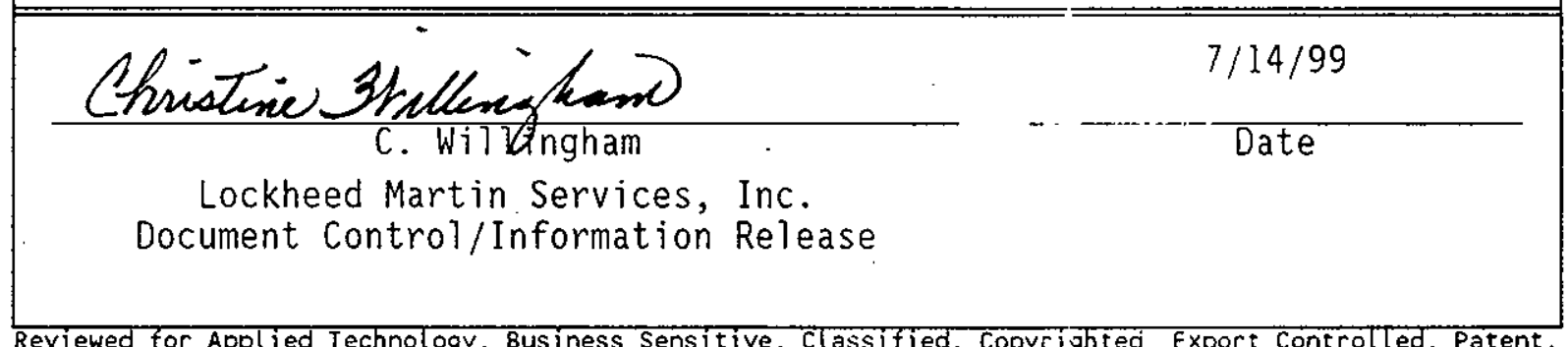

Reviewed for Applied Technology, 8usiness Sensitive, Classified, Copyrighted, Export Controlted, Patent, Personal/Private, Proprietary, Protected CRADA, Trademark, Unclassifies: Controlled Nuclear. Information.

Trademark Disclaimer. Reference herein to any specific comercial proasct, process, or service by trade name, trademark, manufacturer, or otherwise, does not necessarily constitute or imply its endorsement, recommendation, or favoring by the United States Government or any agency thereof or its contractors or subcontractors. The views and opinions of. authors expressed herein do not necessarily state or reflect those of the United States Government or any agency thereof. This report has been reproduced from the best available copy.

Printed in the United States of America.

Available to the U.S. Department of Energy and its contractors from the U.S. Department of Energy office of Scientific and Technical Information, P.0. Box 62, Oak Ridge, TN 37831; Telephone: 423/576-8401.

Available to the public from the U.S. Department of Commerce National Yechnical Information Service, 5285 Port Royal Road, Springfield, VA 22161; Telephone: 703/487-4650. 


\section{NOTICE OF CONSTRUCTION \\ WORK IN TANK FARM WASTE TRANSFER PIT 244-TX DOUBLE-CONTAINED RECEIVER TANK}

The following description and any attachments and references are provided to the Washington State Department of Health (WDOH), Division of Radiation Protection, Air Emissions \& Defense Waste Section as a notice of construction (NOC) in accordance with Washington Administrative Code (WAC) 246-247, Radiation Protection - Air Emissions. WAC 246-247-060, "Applications, registration, and licensing", states "This section describes the information requirements for approval to construct, modify, and operate an emission unit. Any NOC requires the submittal of information listed in Appendix A." Appendix A (WAC 246-247-110) lists the requirements that must be addressed.

Additionally, the following description, attachments, and references are provided to the U.S. Environmental Protection Agency (EPA) as an NOC, in accordance with Title 40 Code of Federal Regulations (CFR), Part 61, "National Emission Standards for Hazardous Air Pollutants." The information required for submittal to the EPA is specified in 40 CFR 61.07. The potential emissions from this activity are estimated to provide less than 0.1 millirem/year total effective dose equivalent to the hypothetical offsite maximally exposed individual, and commencement is needed within a short time. Therefore, this application also is intended to provide notification of the anticipated date of initial startup in accordance with the requirement listed in 40 CFR 61.09(a)(1), and it is requested that approval of this application also will constitute EPA acceptance of this initial startup notification. Written notification of the actual date of initial startup, in accordance with the requirement listed in 40 CFR 61.09(a)(2), will be provided later.

The activities described in this NOC are estimated to provide a potential offsite (unabated) total effective dose equivalent (TEDE) to the hypothetical maximally exposed individual (MEI) of $2.36 \mathrm{E}-02$ millirem per year.

\section{LOCATION}

Pit Designation:

244-TX Double-Contained

Receiver Tank Pump Pit
200 Area:

West
Geographic Coordinates:

North Latitude

$46^{\circ} 33^{\prime} 25^{\prime \prime}$
West Longitude

$119^{\circ} 31^{\prime} 10^{\prime \prime}$

\section{RESPONSIBLE MANAGER}

Mr. R. T. French, Manager

U.S. Department of Energy, Office of River Protection

P.O. Box 550

Richland, Washington 99352

(509) 376-7591 


\section{PROPOSED ACTIONS}

This NOC evaluates the potential emissions associated with activities that might be performed in the pump pit designated in Section 1. These activities include the following:

- Remove or install cover blocks

- Perform inspections

- Install, disconnect, change, and cut up jumpers/blanks or other pit equipment.

- Repair/replace valves, jumpers, pumps, filters, leak detectors, or other instrumentation/equipment

- Perform decontamination activities

- Apply fixative with cover blocks on or off

- Clear drains and check flow of drains

- Unplug transfer lines.

These activities will be performed in accordance with specific work controls and are considered insignificant modifications to an existing, registered emission facility [244-TX double-contained receiver tank (DCRT)]. These activities have been performed many times in the past in this and other pits.

\section{STATE ENVIRONMENTAL POLICY ACT (SEPA)}

The proposed action is categorically exempt from the requirements of the State Environmental Policy Act under WAC 197-11-845.

\section{CHEMICAL AND PHYSICAL PROCESSES}

Chemical and physical processes involved are those activities described in Section 3 . In the past, these activities have been conducted frequently. Performance of these activities is an important part of the environmental cleanup mission on the Hanford Site. This section provides a brief description of the emission unit and a description of each activity listed in Section 3.

\section{5a. Facility Description}

Waste transfer pits are located at transfer piping network intersections and provide access from the surface to process piping and tank risers. Pits are the points where jumpers, pumps, and other equipment are installed to establish waste transfer routings. Leak detection is provided in pits for use during transfers.

The 244-TX DCRT pump pit (Figure 1) is a waste transfer pit that, together with its related equipment, constitutes a short-term storage area for liquid waste and pump pit for waste transfer operations. This DCRT is actively ventilated and consists of an underground concrete structure that contains a filter pit, a pump pit containing three pumps (two agitator pumps and one transfer pump), an instrument pit, and a vault in which a receiver tank is installed. This station provides short-term storage and waste routing for liquid waste pumped from 241-T, 241-TX, and 241-TY Tank Farms, the Plutonium Finishing Plant, and from miscellaneous catch tanks via a tanker truck in the 200 West Area. The agitator pumps are used to keep solids suspended in the tank when plutonium-bearing waste from the Plutonium Finishing Plant or other waste is handled, and the pump also can be used to transfer liquid out of the DCRT when the primary transfer pump is inoperable. Additionally, there are three neutron monitors located underneath the tank to detect the buildup of plutonium. 
The DCRT has a capacity of approximately 31,000 gallons and is constructed of carbon steel. The DCRT is surrounded by a tank vault that acts as a secondary containment vessel. The DCRT and vault are separated by an annular space.

The DCRT and the tank vault annulus are vented through a single exhaust system, stack 296-T-18 (Figure 1). Remote instrument readout and alarm panels for the exhaust system are located in the 244-TX Building and 242-T Evaporator control room.

Outside air enters the DCRT annulus through an air intake equipped with an electric heater, prefilter, and a single stage high-efficiency particulate air (HEPA) filter. The vault and DCRT air streams flow through two of three parallel HEPA filter banks in the filter pit and join into a single line. The exhaust fan and stack are located above ground, outside the filter pit. The exhaust fan design capacity is 250 cubic feet per minute. Fan driven air exits to the atmosphere through stack 296-T-18.

This ventilation system is operating when pit activities are being conducted. However, emissions through the 296-T-18 stack are minimal during the performance of pit activities, because the unused nozzles have or will have a process blank or vapor seal installed before working in the pump pit.

\section{5b. Process Description}

All pit work is preceded by a planning process. For complex work activities, an enhanced work planning process is used that expands the normal planning process to ensure increased field involvement and more detailed review, including lessons learned. This ensures pit work activities are evaluated for special controls considering the degree of contamination in the pit, the type of work to be performed, previous experience in the pit, and the potential for process upsets that could contribute to an environmental release or personnel injury.

Whenever possible, cover blocks remain in place during the performance of pit activities. In addition to the controls listed in Section 6, the following process descriptions also identify actions taken to minimize the potential for contamination or release.

\section{Removal and/or installation of cover blocks:}

Key blocks are removed first. Only blocks necessary to perform intended work are removed. Consideration is given to sliding blocks to minimize the number of blocks to be removed. As discussed in the following, cover blocks are decontaminated and/or covered with fixative before removal. Cover blocks are raised (with appropriate equipment) a minimum distance to safely allow a radiation protection technician to perform a dose rate and contamination survey. Cover blocks are wrapped in plastic and set down in a specially prepared laydown area. On completion of activities, the plastic wrap is removed from the cover blocks and the cover blocks are re-installed in their original position and orientation. Post-job surveys are performed.

\section{Inspections:}

Inspections, such as visual, video, or nondestructive inspections, could be performed with cover blocks in place or removed depending on cover block design and special circumstances surrounding the inspection.

Installation, disconnection, changing, leak testing, and cutting up jumpers/blanks or other pit equipment: Before entry into a pit, an evaluation is made by engineering and/or operations personnel to determine the transfer routing configuration after pit work is complete. On removal of cover blocks, a visual inspection of pit contents is made to verify present configuration. Jumper work could be preceded by flushing the appropriate transfer lines with water. Jumper work is accomplished remotely, using a crane to maneuver heavy equipment and parts. Installation, disconnection, and/or changing jumpers/blanks are accomplished 
by slowly loosening the jumper/blank at the connector head. The required jumper/blank is positioned and tightened to the new connector heads. If the process line or equipment being worked on is connected physically to an active waste transfer system, or if the line is to be left unused, a cap, blank, or equivalent is installed on all open nozzles not connected to jumpers.

Leak testing of newly installed jumpers/blanks normally is performed with pressurized water before initiating waste transfers. Occasionally, a jumper leak test is performed during the initial stages of the transfer. In either case, cover blocks are in place before leak testing is performed.

Cutting up unusable pit equipment (usually jumpers/blanks) is accomplished remotely using hydraulic shears or a low revolutions per minute portable band saws.

Repairing/replacing valves. jumpers. pumps. leak detectors, or other instrumentation/equipment: Tools such as impact wrenches, T-bars, and pike poles are used to repair or replace pit equipment. All equipment coming out of the pit is contained or decontaminated. Removable contamination on the outer-most container will not exceed 1,000 disintegrations per minute /100 square centimeters beta/gamma and 20 disintegrations per minute/100 square centimeters alpha before removal from the bullpen.

\section{Decontamination activities:}

Removable contamination in the accessible portions of the pit is reduced to less than 100,000 disintegrations per minute/100 square centimeters beta/gamma and 2,000 disintegrations per minute/100 square centimeters alpha by washing, or an approved fixative is applied to pit surfaces. Initial washing with a low pressure (125 pounds per square inch gauge), or high pressure (3,000 pounds per square inch gauge) 'whirly' is accomplished through a port in the pit cover blocks. Additional decontamination activities (with the cover block off) include the use of chemicals, peel and strip paints, water, or manual scrub brushes.

\section{Applying fixative with cover blocks on or off:}

Fixatives can be applied to pit surfaces through a port in the cover block using a 'whirly' or by fogging. A hand held sprayer is used to apply fixatives to local areas within the pit when the pit cover block is off. Past lessons learned have lead to the adoption of criteria to ensure the spray wands are of adequate length to ensure proper application of fixative to pit and equipment surfaces.

\section{Clearing drains and checking the flow of drains:}

These operations can be performed with cover blocks on or off, depending on the design of cover blocks and the special circumstances surrounding the operations to be performed. Pit drains are checked using water from a tanker truck or another source. Water at a flow rate of approximately 20 gallons per minute is added to a pit drain line and subsequently monitored to verify the pit drains are free of restrictions. At times it might be necessary to pump the DCRT that receives the water after the water passes through the pit drain if the volume of test water approaches the capacity of the DCRT.

Plugged drains are cleared by either flushing with water and/or using a retrieval tool to remove debris from the drain. The water supply line is purged of air by filling with water before insertion into the pit floor drain. Water supply valves are opened slowly to minimize splashing. Pressures up to 50 pounds per square inch gauge could be used. Pressures above 50 pounds per square inch gauge require approval from the engineering organization. When possible, cover blocks remain in place and work is accomplished through a penetration in the cover block.

\section{Unplug Transfer Lines:}

The waste transfer operations involve the pumping of liquid waste that contains dissolved solids. These solids can precipitate out of solution anywhere in the transfer path and cause blockage. If blockage is 
detected in the system, flushing the lines with hot water is necessary. The hot water is introduced to the system to be flushed through a pressure manifold by piping connected directly to a jumper or nozzle. These operations are performed with the cover blocks off.

Other techniques to free blockages could include pressurization, temporary jumpers, and hydraulic scouring. All piping connections are designed to be leak tight and the pit cover block will be installed before pressurization. If pressurization beyond that obtained from the tank farms water system or supply truck (i.e., approximately 150 pounds per square inch gauge) is necessary to remove blockage, an engineering evaluation will be performed to determine the maximum allowable pressure for operation.

\section{PROPOSED CONTROLS}

The controls used during the performance of pit activities are based on a graded approach. Pit activities that have an increased potential for air emissions or personnel injury require special controls. Activities with a low potential for air emissions or personnel injury require less controls. The following controls are used for the pit activities discussed in this NOC.

1. Pre-job and post-job radiation surveys are performed by radiation protection technicians. Radiation work permits specify permissible occupational radiological limits during activities. Radiation control technicians survey and release equipment, inspect and approve required containment, and provide radiological surveys to verify compliance to radiation work permit limits.

2. Pit work is shut down (or not initiated) when sustained wind speeds exceed 25 miles per hour or are predicted to do so by Hanford Meteorological Station personnel for the period of planned pit work.

3. Fixatives could be applied inside the pit (with cover blocks on or off) or accessible portions of the pit decontaminated to less than 100,000 disintegrations per minute/100 square centimeters beta-gamma and 2,000 disintegrations per minute/100 square centimeters alpha.

4. When cover blocks are removed, a fall protection handrail is installed. This handrail is draped in plastic forming a contamination barrier. The plastic extends to the top of the pit and is taped or sealed at the top of the pit. Decontamination of the containment barrier is conducted as required by the job specific radiation work permit.

5. If the bullpen is to be left unattended at any time, a temporary cover is placed over the pit or the cover blocks are reinstalled. A typical open top bullpen will be used to minimize potential emissions. The size of the bullpen could vary from job to job; however, a typical bullpen measures approximately 25 feet wide by 30 feet long. The height is approximately 8 feet near the walls and increases to approximately 14 feet near the opening. The opening in the top of this size bullpen is approximately 11 feet by 22 feet, which represents an area approximately one-third the size of a fully opened roof.

6. Affected transfer lines could be flushed (cover blocks in place) with water before removing jumpers.

7. Radiation control technicians monitor the affected work area while jumpers are being removed from nozzles. Jumpers removed from the pit are drained of free liquid and decontaminated or contained before removal. The outer-most container will not exceed 1,000 disintegrations per minute/100 square centimeters beta/gamma and 20 disintegrations per minute/100 square centimeters alpha before removal from the bullpen. 
8. The following additional controls will be implemented for any pit activity that has a potential for exposing additional waste (to the pit environment), which would otherwise remain contained in transfer lines or other pit equipment. Primary activities requiring the additional controls include jumper change outs, valve and nozzle replacements, and cutting up contaminated equipment.

- An open top bullpen designed to minimize the top opening will be used. The cover blocks will be removed. At the end of the work shift, the cover blocks will be re-installed.

- Active ventilation of the bullpen will be used (after removal of the cover blocks) during work activities to minimize radiological releases. Air inflow will be achieved by using a 1,000 cubic feet per minute exhauster, which will achieve approximately six (or more) air changes per hour (assuming all air spaces of the bullpen and pit are evacuated at the same rate).

Additional special controls will be determined by using the approved containment guideline matrix from RPP Administration, HNF-IP-0842, Volume VII, Section 3.1, "Radiological Control", latest revision.

Figure 2 shows a typical portable exhauster that will provide active ventilation within the bullpen. These exhausters contain a pre-filter, one HEPA filter, and a blower that draws air through the filters and pushes air out an exhaust port.

\section{DRAWINGS OF CONTROLS}

Figure 1 presents a flow diagram for the 244-TX DCRT during normal operations and Figure 2 shows a typical portable exhauster that provides active ventilation within the bullpen. The portable exhausters contain a pre-filter, one HEPA filter and a blower that draws air through the filters and pushes air out an exhaust port. Process controls are administrative.in nature and follow the Hanford Site radiological control and as low as reasonably achievable (ALARA) principles. Drawings of these controls are not applicable.

\section{RADIONUCLIDES OF CONCERN}

Radionuclides of concern for the 244-TX DCRT are presented in Attachment 1. These radionuclides represent a conservative best basis list of radionuclides associated with tank waste in the 241-T, $-\mathrm{TX}$ and -TY Tank Farms, and are judged to be representative of current contamination in the pits and the tank waste that will pass through 244-TX DCRT pump pit.

\section{MONITORING}

There is no active, permanently installed, ventilation for the 244-TX pit. Emissions from the portable exhauster will be verified as low via one of the following two methods: (1) nondestructive analysis (using a procedure approved by WDOH) of each exhauster's HEPA filter after each work package is completed or (2) maintaining log-type records documenting each exhauster's history of use for the current calendar year, including location, start/stop date and time, total hours of operation, and purpose of operation. In this case, nondestructive analysis on the HEPA filters on the exhausters will be performed at the end of that calendar year.

Continuous radiation control technician coverage is provided while the pit remains open. Monitoring consists of contamination surveys during the pit activities. 
Air samples are taken at all times the bullpen is occupied and the exhauster is operating for those operations described in Section 6, last bullet) for the period just before the cover block is removed and extending through cover block re-installation. All environmental air measurement sample analyses are performed in accordance with the applicable quality assurance requirements of 40 CFR 61, Appendix B, Method 114, during the actual work activity to verify containment of radionuclides. Pre-job and post-job surveys also are performed to verify containment.

\section{ANNUAL POSSESSION QUANTITY}

The annual possession quantity was conservatively estimated, based on the following.

1. The inventory of radionuclides for the single-shell tanks within the 241-T, -TX, and -TY Tank Farms (Attachment 1) was obtained from the Tank Waste Information Network System 2, which is available on the internet (http://twins.pnl.gov:8001). Using the tank volumes contained within the "Waste Tank Summary Report for Month Ending March 31, 1999 (HNF-EP-0182-132), and using the conservative assumption that all radionuclides were in solution, the concentration of the radionuclides was calculated by dividing the tank isotope inventories by the volume of waste within the tank. The highest concentration for each isotope was used in calculating the annual possession quantity (Attachment 2). These concentrations represent a conservative estimate of the inventory that is expected to be contained within the 244-TX DCRT pump pit.

2. A potential combined drain back of 500 gallons of double-shell tank waste from a transfer line during all pit entry during a year was used. Operational experience indicates that less than 500 gallons will drain back; however, for conservatism, 500 gallons is assumed. As shown in Attachment 3, the drain back is assumed to contain $3.95 \mathrm{E}+03$ curies.

3. Once drain back to the pit is complete, 490 gallons of the 500 gallons drains from the pump pit to the DCRT. Ten gallons remains in the pit as a radionuclide inventory of liquids and solids. This inventory of $7.89 \mathrm{E}+01$ curies is assumed to include radionuclides present in the pit before the drain back, as well as the residual radionuclides remaining after drainage to the DCRT (Attachment 4).

4. Therefore, the annual possession quantity becomes the sum of radionuclides present in the drain back (3.95 E+03 curies per Item 2), plus the radionuclides present in the liquids and solids remaining in the pit (7.89 E+01 curies per Item 3), for a total annual possession quantity of $4.02 \mathrm{E}+03$ curies (Attachment 5).

\section{PHYSICAL FORM}

All radionuclides listed are present as liquids or particulate solids.

\section{RELEASE FORM}

The release form is radionuclide particulate solids or aerosols. 


\section{RELEASE RATES}

The release rate from the pit becomes the sum of a conservative concentration of particulate radionuclides potentially airborne due to the splashing of drain back to the pit (1.58 E-01 curies per year), plus the radionuclides partitioned from the remaining 10 gallons of liquid and solid waste (7.89 E-02 curies per year) after 490 gallons drains to the DCRT. The total release rate is the sum of these two values (2.37 E-01).

The partitioning fraction used for the splashing of drain back is 8.0 E-05 per DOE-HDBK-3010-94, "Airborne Release Fractions/Rates And Respirable Fractions For Nonreactor Nuclear Facilities". The selected airborne release fraction is midway between an aqueous solution and the bounding condition (consistent with the approved 152-ER and 242-A Lift Station NOC). The value 8.0 E-05 was used to account for the fact that the drain back height into the pit would occur from less than 3 meters. A partition fraction of 1.0 E-03 (40 CFR 61, Appendix D) was used for the 10 gallons of liquid remaining in the pit.

\section{LOCATION OF MAXIMALLY EXPOSED INDIVIDUAL}

The conservative location of the maximally exposed individual ${ }^{*}$ used for this NOC is 22,000 meters Southeast of the 200 West Area.

(* "Calculating Potential to Emit Releases and Doses for FEMPs and NOCs", HNF-3602.)

\section{TOTAL EFFECTIVE DOSE EQUIVALENT TO THE MAXIMALLY EXPOSED INDIVIDUAL}

The TEDE to the MEI for work in the 244-TX DCRT pump pit is assumed to be the sum of the dose from particulate radionuclide releases from the splash model, plus the dose from radionuclides partitioned from the liquid and solid waste remaining (10 gallons) after 490 gallons drain to the DCRT (Attachments 3 and 4).

Using the analysis discussed in Section 13, the offsite TEDE attributed to the drain back splashing is 1.89 E-02 millirem per year. The offsite total effective dose equivalent attributed to the residual ( 10 gallons) solid/liquid waste is $4.72 \mathrm{E}-03$ millirem per year. The total offsite TEDE is the sum, or $2.36 \mathrm{E}-02$ millirem per year using this method.

\section{COST FACTOR IF NO ANALYSIS}

The pit work described in this NOC will represent a nonsignificant modification to an existing facility as noted in Section 3. The controls proposed in Section 6 are consistent with the Hanford Site radiation control and as low as reasonably achievable principles, and are proposed as representing as low as reasonably achievable control technology.

\section{DURATION OR LIFETIME}

The 244-TX DCRT is expected to remain in operation through fiscal year 2025. 


\section{STANDARDS}

The potential TEDE received by the offsite hypothetical highest receptor, resulting from the proposed operation of the emission unit, is less than 0.1 millirem per year. The portable ventilator units described in this NOC are off-the-shelf, commercially available units. The following control technology standards have been considered. This section discusses compliance with major sections of these standards and provides justification to support adequacy of the design for sections of these standards that are not met.

American Society for Engineers (ASME)/American National Standards Institute (ANSI) AG-1 This equipment specific code consists of five primary sections that are applicable to these ventilator units. The applicable sections are fans (Section BA), ductwork (Section SA), HEPA filters (Section FC), dampers (Section DA), and quality assurance (Section AA).

The fan section of AG-1 covers construction and testing requirements for fans. It cannot be shown that the fan used in these portable ventilator units meets the AG-1 requirements. It is not known whether fans for these ventilator units were fabricated and tested to the Air Movement and Control Association (AMCA) standards for performance, vibration criteria, and noise level, nor can it be determined what standards were used for the fabrication and testing of these particular fans.

However, considering the intended service of these ventilator units, it is judged that requirements of the AG-1 standard for fans is not necessary. This is justifiable because these exhausters are used in a batch mode for short periods (days). Also, the operations these units support are manned continually, which allows for prompt detection of malfunctions and prompt performance of repairs. In addition, these ventilator units have a long history of successful performance in applications similar to those described in this NOC.

AG-1 also specifies requirements for ductwork that includes material, fabrication, and testing criteria to ensure structural integrity of the ductwork. The use of flexible ductwork is permitted by AG- 1 and the ventilators used in this application will use flexible ductwork, or fixed connections (sheet metal shroud bolted to the exhauster and sealed to the bullpen wall). However, it cannot be shown that the ductwork to be used in this application meets the criteria specified in the AG-1 standard. The ductwork used in this application is purchased as standard-flex duct that is suitable for the intended service, but it was not and will not be pressure tested after installation. The design of the ductwork is considered adequate for the intended use for the reasons provided previously, i.e., batch operation of short duration, continually manned operation, and satisfactory performance history. Also, because this ductwork is used on the inlet side of the ventilators, the ventilators will be under negative pressure and a potential leak path will be into the duct.

The HEPA filter criteria identified in AG-1 is that which was located previously in military specification 51068 and ASME N509. The filters used in these ventilator units meet all the criteria except for two areas dealing with filter qualification testing. Justification for this exception was discussed with and approved by WDOH at the December 1998 Routine Technical Assistance Meeting. A WDOH approved temporary deviation is currently in place to satisfy this issue (WDOH AIR 99-507).

AG-l also addresses construction and testing criteria for dampers. It cannot be shown that the dampers (valves) meet the applicable AG-1 criteria. The valves associated with these units are used only for isolation when the system is transported and throttling during operation. The requirements of AG-1 are not necessary for this application.

The quality assurance section of AG-1 relies on ASME NQA-1, which is used to ensure the components, and ultimately the system, will function reliably as designed. These ventilator units were built to the manufacturer's quality assurance program, which is not available for evaluation to NQA-1. However, as 
noted previously, the intended use of the ventilators, the conditions under which the ventilators will be operated, and the experience gained to date, provide adequate justification that the system will function reliably as designed.

AG-1 requirements for the filter housing are discussed under ASME/ANSI N509. The remaining sections of AG-1 are not applicable to this application for reasons previously discussed, i.e., batch operation of short duration, continually manned operation, and satisfactory performance history.

\section{ASME/ANSI N509:}

This standard deals with the individual components and how these relate to the overall system. Of primary importance are the sections regarding the filter housing and the heater.

The filter housings do not meet the N509 criteria; however, the filter housings are designed and constructed to meet pressure, corrosion and humidity necessary for their intended application. The filter sealing surfaces of the filter housing are sufficiently flat, and a tightening mechanism is in place to ensure proper seating of the HEPA filter.

These exhausters do not contain a heater. However, no heater is needed for this application. The purpose of the heater is to maintain the relative humidity of the air stream below 70 percent. Because the application of these ventilator units is for short durations and the air being drawn through the system is primarily atmospheric air, condensation has not been and is not expected to be a concern.

\section{ASME/ANSI N510:}

This standard pertains to the testing of nuclear air cleaning systems. Of primary importance are the criteria addressing pressure decay testing and aerosol testing of the HEPA filter.

The HEPA filter on the ventilation unit is not subjected to pressure decay testing as no added benefit is expected considering the intended service of the unit. Also, because the system is operated under negative pressure, potential leak paths are into not out of the system. This, in addition to reasons provide previously, i.e., batch operation of short duration, continually manned operation, and satisfactory performance history; is considered sufficient justification for not performing pressure decay testing.

The single HEPA filter on the ventilator unit cannot be aerosol tested per N510 criteria. The current method for testing the filter is proceduralized (procedure available upon request) and includes injecting an aerosol upstream before the filter and sampling upstream and downstream of the filter for penetration. A measurement is taken to determine the amount of aerosol challenging the upstream face of the HEPA filter. This establishes the 100 percent baseline point to accurately determine penetration through the HEPA filter. Considering the intended service these units are providing, and because only one HEPA filter is used, this test is considered an acceptable method to verify HEPA filter integrity.

\section{ANSI/ASME NQA-1:}

Quality assurance is addressed by HNF-MP-599, latest revision, "Project Hanford Quality Assurance Program Description" (Chapter 2.0, Section 3.3 and Chapter 7.0, Section 3.2) and by HNF-0528-3, "National Emission Standards for Hazardous Air Pollutants (NESHAP) Quality Assurance Project Plan for Radioactive Airborne Emissions", (all of Sections 2.0, 3.0 and 5.0) as a compatible alternative to NQA-1.

\section{ANSI/ASME NQA-2:}

The standard is no longer an active National Standard and has been incorporated into NQA-1. Compliance with NQA-1 is addressed. 
40 CFR 60. Appendix A:

Because this is a portable ventilation source with no inline sampling capability, Methods 1, 1A, 2, 2A, 2C, $2 \mathrm{D}, 4,5$, and 17 do not apply.

ANSI N13.1:

Continuous monitoring is not required, thus compliance with this standard does not apply. Periodic confirmatory samples are taken as described in Section 9.

Current operations and testing methods are proposed as compatible and adequate to demonstrate protection of the public.

\section{Conditions and Clarifications}




\section{Signatures}

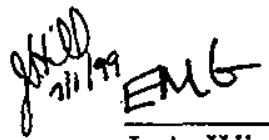

\section{J. A. Winterhalder, WMH}
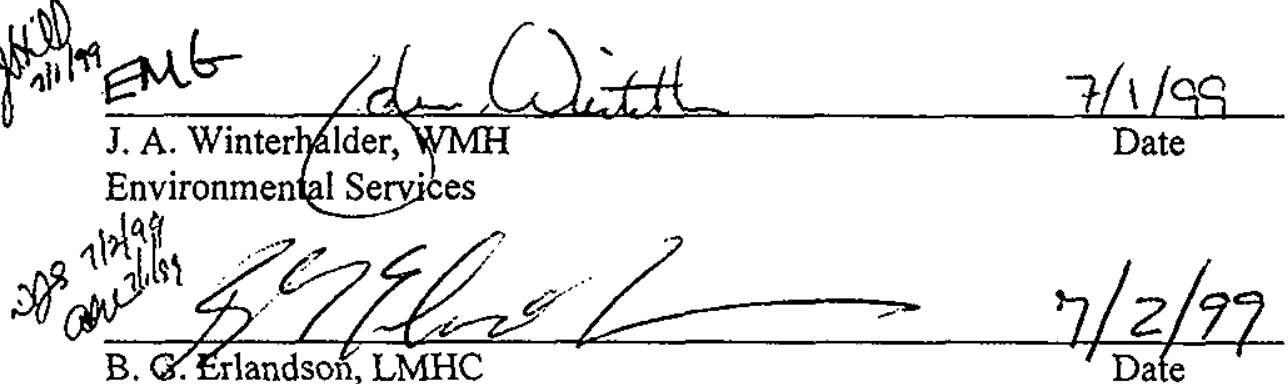

B. 6. Erlandson, LMHC

Environmental Manager

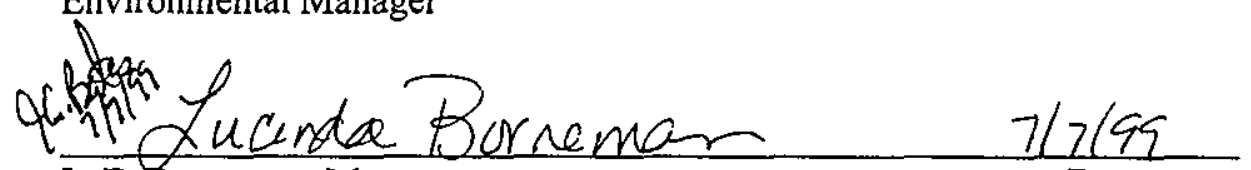

L. E. Borneman, Manager

Date

River Protection Project

Fluor Daniel Hanford, Inc.

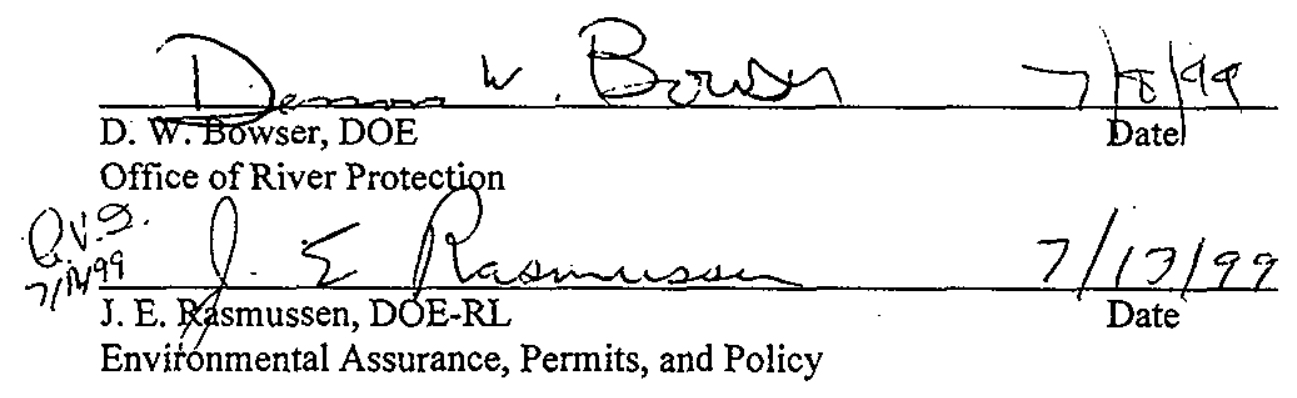

A. W. Conklin, WDOH

Date

Division of Radiation Protection,

Air Emissions \& Defense Section 


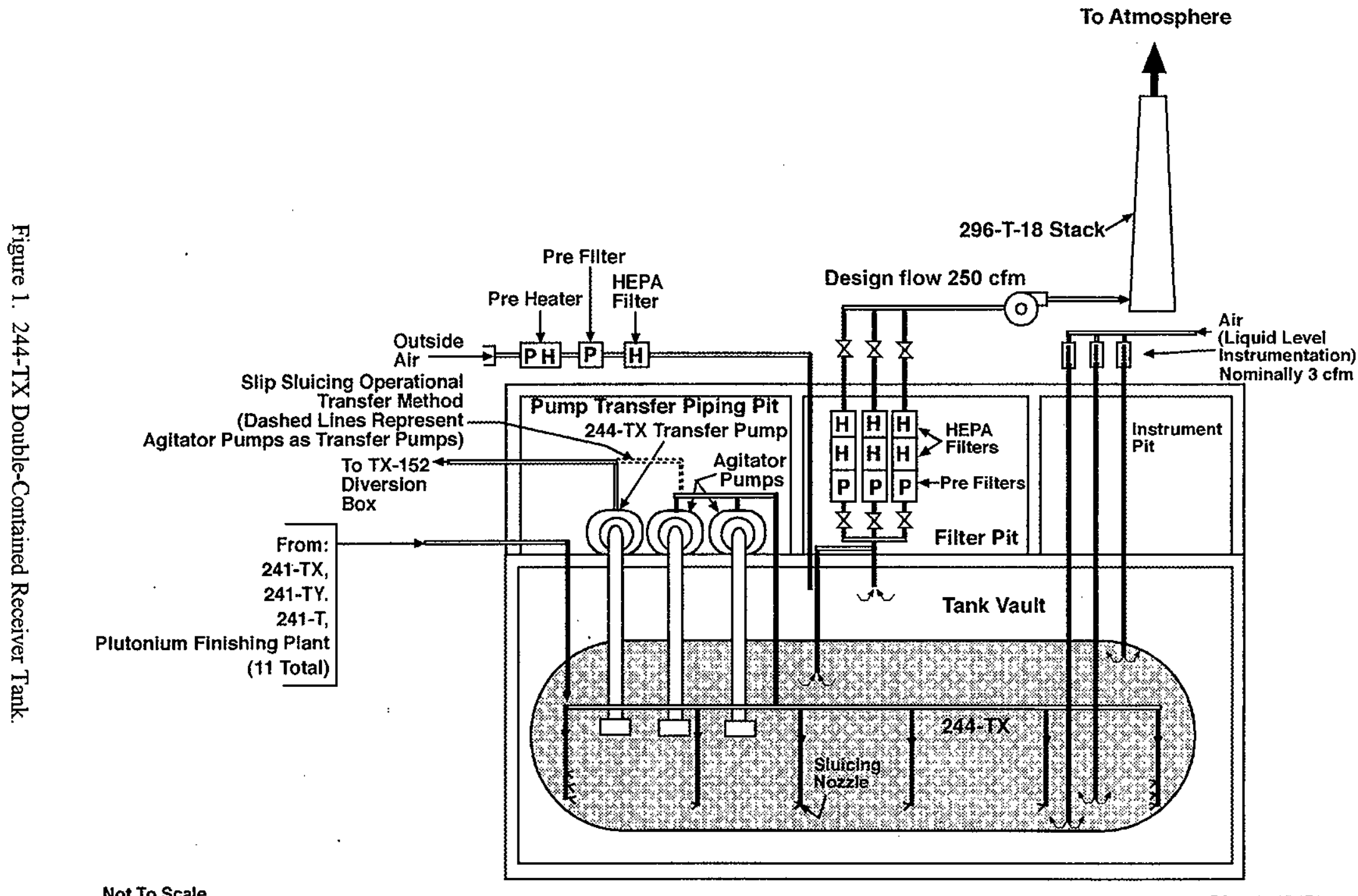




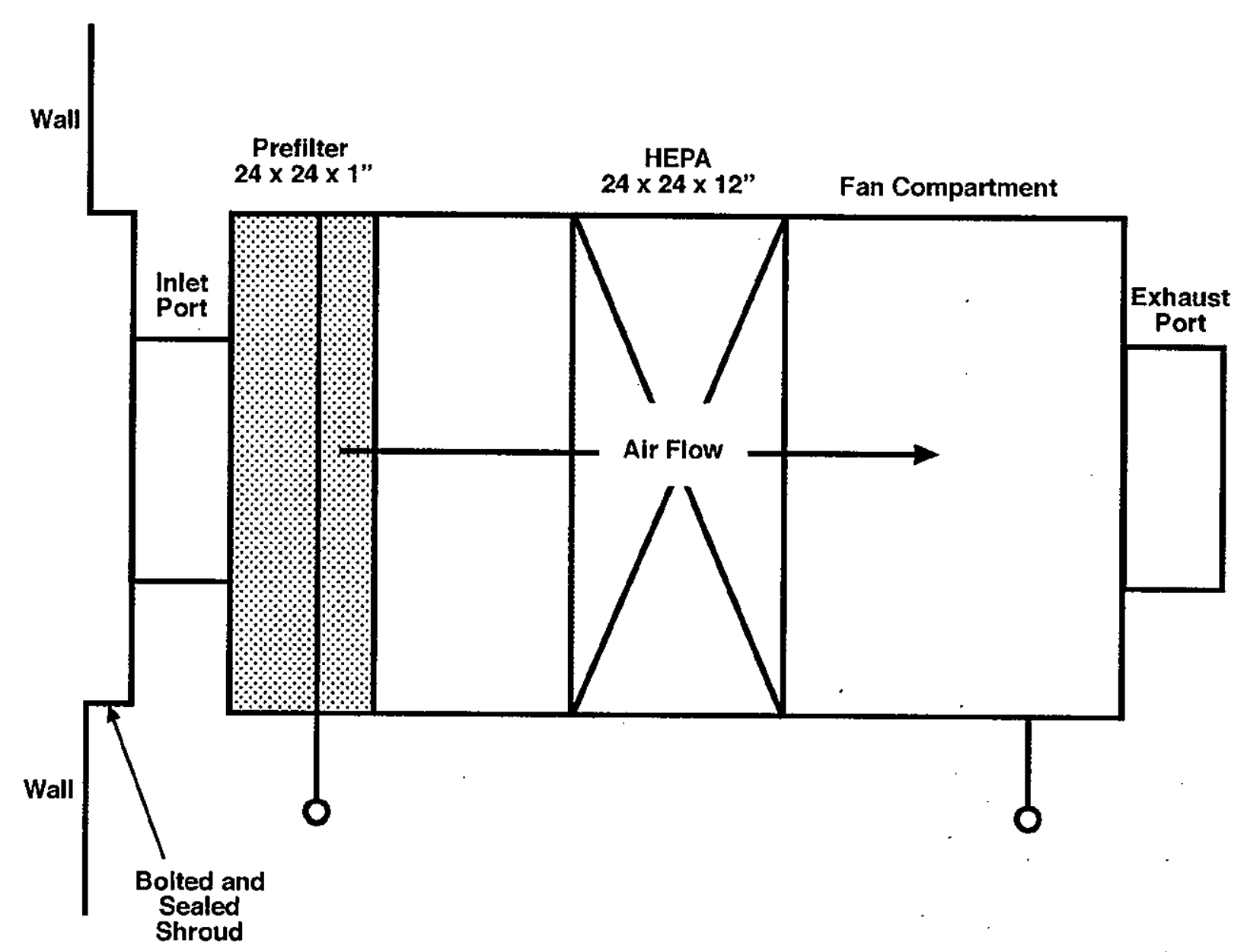

Not To Scale

H99060091.1R1

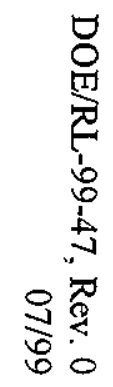




\section{ATTACHMENT 1 OF NOC \\ 241-T, -TX, AND -TY TANK FARM TANK INVENTORY}

(Consisting of 4 pages, including cover) 


\section{Error}

An error occurred while processing this page. See the system log for more details. 


\section{Error}

An error occurred while processing this page. See the system log for more details. 


\begin{tabular}{|c|c|c|c|c|}
\hline Analy & $T Y=103$ & TY-104 & TY-105 & TY-106 \\
\hline $3 \mathrm{BH}$ & $2.45 E+01$ & $1.74 \mathrm{E}-01$ & $3.24 E+00$ & $8.63 \mathrm{E}-03$ \\
\hline $14 C$ & $.04 E+00$ & $9.36 \mathrm{E}-01$ & $1.05 E+00$ & \\
\hline $59 \mathrm{Ni}$ & $41 \mathrm{E}-01$ & 1.05E-01 & $1.27 \mathrm{E}-01$ & \\
\hline $63 \mathrm{Ni}$ & $20 E+01$ & $9.61 \mathrm{E}+00$ & $1.15 E+01$ & \\
\hline $60 \mathrm{Co}$ & $53 E+00$ & $22 \mathrm{E}+\infty$ & $6.65 E+00$ & $2.73 E-04$ \\
\hline $79 S e$ & 01 & $7.36 E-03$ & $9.45 E-02$ & $2.52 E-04$ \\
\hline & & $E+04$ & $2.56 \mathrm{E}+05$ & $9.76 E+03$ \\
\hline $90 \mathrm{Sr}$ & & $3.18 \mathrm{E}+04$ & $2.56 \mathrm{E}+05$ & $9.76 \mathrm{E}+03$ \\
\hline $937 r$ & & $3.49 E-02$ & EE-01 & $1.20 \mathrm{E}-03$ \\
\hline & & -02 & $E-01$ & -03 \\
\hline & & & +01 & \\
\hline & & & & \\
\hline 113 & & & $=00$ & \\
\hline & & & E-02 & \\
\hline & & & & \\
\hline & & & & \\
\hline & & & & \\
\hline & & & & \\
\hline & & & & \\
\hline & & & & \\
\hline & & & & \\
\hline & & & & \\
\hline & & & & \\
\hline & & & & \\
\hline & & & & \\
\hline & & & & \\
\hline & & & & \\
\hline & & & & \\
\hline & & & & -07 \\
\hline & & & & \\
\hline & & & -06 & -07 \\
\hline & & & & \\
\hline & & & & \\
\hline & & & & \\
\hline & & & & \\
\hline & & & & -05 \\
\hline & & & & \\
\hline & & 4. & & \\
\hline & & & & \\
\hline & & & & \\
\hline & & & & \\
\hline & & & & \\
\hline & & & & \\
\hline & & & & \\
\hline & & & & \\
\hline $244 \mathrm{~cm}$ & -02 & $1.65 \mathrm{E}-03$ & $1.42 E-04$ & 3.7 \\
\hline
\end{tabular}




\section{ATTACHMENT 2 OF NOC \\ 241-T, -TX AND -TY CALCULATED TANK CONCENTRATIONS}

(Consisting of 4 pages, including cover) 


\section{Error}

An error occurred while processing this page. See the system log for more details. 


\section{Error}

An error occurred while processing this page. See the system log for more details. 


\begin{tabular}{|c|c|c|c|c|c|c|c|}
\hline & TY-101 & $T Y-102$ & $T Y-103$ & TY-104 & TY-105 & TY-106 & $\begin{array}{c}\text { MAXIMIUM } \\
\text { CONCENTRATION }\end{array}$ \\
\hline WASTE VOLUME GALLONS & 118,000 & 64,000 & 162,000 & 46,000 & 231,000 & 17,000 & CURIEJGALLON \\
\hline \multicolumn{8}{|l|}{$\begin{array}{l}\text { CONCENTRATION } \\
\text { (CURIE/GALLON) }\end{array}$} \\
\hline $3 \mathrm{H}$ & 5.65E-06 & 2.95E-04 & $1.51 \mathrm{E}-04$ & $3 . \overline{78 E}-06$ & $1.40 \mathrm{E}-05$ & $5.08 \mathrm{E}-07$ & $5.90 E-04$ \\
\hline $14 C$ & 5.41E-06 & $6.22 E-06$ & 6.42E-06 & 2.03E-05 & $4.55 \mathrm{E}-06$ & $6.06 \mathrm{E}-06$ & $1.84 \mathrm{E}-04$ \\
\hline $59 \mathrm{Ni}$ & 3.39E-06 & $4.70 \mathrm{E}-06$ & $2.72 E-06$ & $2.28 \mathrm{E}-06$ & $5.50 \mathrm{E}-07$ & $1.99 \mathrm{E}-08$ & $4.61 \mathrm{E}-05$ \\
\hline 63Ni & $3.08 \mathrm{E}-04$ & $4.48 \mathrm{E}-04$ & $2.59 E-04$ & 2.09E-04 & $4.98 \mathrm{E}-05$ & $1.80 \mathrm{E}-06$ & 4.31E-03 \\
\hline $60 \mathrm{Co}$ & 2.09E-05 & $5.34 \mathrm{E}-06$ & $9.44 E-06$ & $4.83 E-05$ & $2.88 \mathrm{E}-05$ & 1.61E-08 & $1.60 \mathrm{E}-04$ \\
\hline $79 \mathrm{Se}$ & $2.24 E-07$ & $4.41 \mathrm{E}-06$ & $2.25 E-06$ & $1.60 \mathrm{E}-07$ & $4.09 \mathrm{E}-07$ & $1.48 \mathrm{E}-08$ & $9.03 \mathrm{E}-06$ \\
\hline $90 Y$ & 6.33E.02 & $2.69 E-02$ & 5.82E-01 & $6.91 \mathrm{E}-01$ & $1.11 E+\infty$ & $5.74 \mathrm{E}-01$ & $2.87 \mathrm{E}+00$ \\
\hline $90 \mathrm{~s} r$ & $6.33 \mathrm{E}-02$ & $2.69 E-02$ & $5.82 \mathrm{E}-01$ & 6.91E-01 & $1.11 \mathrm{E}+00$ & $5.74 E-01$ & $2.87 \mathrm{E}+00$ \\
\hline $93 \mathrm{Zr}$ & $1.07 E-06$ & $2.16 \mathrm{E}-05$ & 1.10 E-05 & $7.59 E-07$ & $1.94 \mathrm{E}-06$ & $7.06 \vec{E}-08$ & 4.44E-05 \\
\hline $93 \mathrm{mNb}$ & 8.98E-07 & $1.58 \mathrm{E}-05$ & $8.02 E-06$ & 6.37E-07 & $1.64 \mathrm{E}-06$ & $5.94 \mathrm{E}-08$ & $3.21 E-05$ \\
\hline 99Tc & $4.57 \mathrm{E}-05$ & $5.61 \mathrm{E}-06$ & $1.01 \mathrm{E}-04$ & $1.97 \mathrm{E}-04$ & $1.90 E-04$ & $6.29 \mathrm{E}-04$ & $1.56 \mathrm{E}-03$ \\
\hline 106Ru & $1.13 \mathrm{E}-13$ & $8.09 E-09$ & $3.88 \mathrm{E}-09$ & $8.98 \mathrm{E}-14$ & $1.85 \mathrm{E}-13$ & $6.71 \mathrm{E}-15$ & $1.79 E-08$ \\
\hline $113 \mathrm{mcd}$ & 2.65E-06 & $1.10 \mathrm{E}-04$ & 5.54E-05 & $1.93 E-06$ & $4.76 E-06$ & $1.72 E-07$ & $2.34 E-04$ \\
\hline $125 \mathrm{Sb}$ & $0.00 E+00$ & $1.92 \mathrm{E}-04$ & $9.63 \mathrm{E}-05$ & 1.87E-07 & 4.11E-07 & $1.49 E-08$ & $2.80 E-03$ \\
\hline $126 \mathrm{Sn}$ & $3.37 E-07$ & $6.66 \mathrm{E}-06$ & $3.38 \mathrm{E}-06$ & 2.41E-07 & $6.15 \mathrm{E}-07$ & $2.23 \mathrm{E}-08$ & $1.36 \mathrm{E}-05$ \\
\hline $129 !$ & $2.92 E-07$ & $1.35 E-07$ & $2.98 \mathrm{E}-07$ & $9.96 \mathrm{E}-09$ & $1.99 \mathrm{E}-07$ & $9.18 \mathrm{E}-10$ & $1.14 E-06$ \\
\hline $134 \mathrm{Cs}$ & $6.71 E-08$ & $3.30 \mathrm{E}-06$ & $1.59 E-06$ & $6.61 \mathrm{E}-08$ & $3.85 \mathrm{E}-09$ & $1.86 \mathrm{E}-10$ & $2.32 E-04$ \\
\hline $137 \mathrm{Cs}$ & $1.46 E-03$ & 1.97E-02 & $9.20 \mathrm{E}-02$ & $2.39 E-01$ & $4.55 \mathrm{E}-02$ & $9.35 E-02$ & $1.05 E+00$ \\
\hline $137 \mathrm{mBa}$ & $1.38 \mathrm{E}-03$ & $1.86 \mathrm{E}-02$ & $8.70 \mathrm{E}-02$ & 2.26E-01 & 4.42E-02 & $8.88 \mathrm{E}-02$ & $9.96 \mathrm{E}-01$ \\
\hline $151 \mathrm{Sm}$ & $8.32 E-04$ & $1.56 \mathrm{E}-02$ & $7.90 \mathrm{E}-03$ & $5.93 \mathrm{E}-04$ & $1.52 \mathrm{E}-03$ & 5.51E-05 & $3.18 \mathrm{E}-02$ \\
\hline 152Eu & $5.14 E-07$ & $4.81 \mathrm{E}-06$ & $3.41 E-06$ & 1.15E-06 & 1.91E-06 & $1.61 \mathrm{E}-07$ & $2.28 E-05$ \\
\hline 154EU & $4.65 E-06$ & 7.31E-04 & $3.65 \mathrm{E}-04$ & $3.57 \mathrm{E}-06$ & $8.01 E-06$ & $2.89 \mathrm{E}-07$ & $7.52 \mathrm{E}-03$ \\
\hline 155Eu & $3.61 \mathrm{E}-05$ & 2.89E.04 & $2.20 \mathrm{E}-04$ & 8.35E-05 & $1.44 \mathrm{E}-04$ & 1.21E-05 & $8.87 E-03$ \\
\hline $226 R a$ & $5.65 E-11$ & $2.48 \mathrm{E}-10$ & $1.35 \mathrm{E}-10$ & $3.74 \mathrm{E}-11$ & $1.12 \mathrm{E}-10$ & $4.04 E-12$ & 3.37E-09 \\
\hline $227 A C$ & 2.92E-10 & $1.56 \mathrm{E}-09$ & $8.40 \mathrm{E}-10$ & $1.93 \mathrm{E}-10$ & 5.71E-10 & 2.06E-11 & 3.93E-07 \\
\hline 228Ra & $1.62 \mathrm{E}-15$ & $3.36 E-07$ & $1.88 \mathrm{E}-07$ & $4.00 \mathrm{E}-15$ & $7.32 \mathrm{E}-15$ & $6.12 \mathrm{E}-16$ & $6.72 E-07$ \\
\hline 229Th & $3.15 E-13$ & $7.78 \mathrm{E}-09$ & $4.35 \mathrm{E}-09$ & $7.76 \mathrm{E}-13$ & $1.42 \mathrm{E}-12$ & $1.19 \mathrm{E}-13$ & $5.81 \mathrm{E}-08$ \\
\hline 232Th & $3.00 \mathrm{E}-16$ & 2.06E-08 & 1.14E-08 & $2.11 \mathrm{E}-16$ & $5.54 E-16$ & $2.00 \mathrm{E}-17$ & $4.12 \mathrm{E}-08$ \\
\hline $231 \mathrm{~Pa}$ & $6.41 E-10$ & $6.38 \mathrm{E}-09$ & $3.34 \mathrm{E}-09$ & $4.26 \mathrm{E}-10$ & $1.24 \mathrm{E}-09$ & $4.48 \mathrm{E}-11$ & 5.81E-07 \\
\hline $232 \mathrm{U}$ & $1.14 \mathrm{E}-10$ & $6.44 E-08$ & $7.16 \mathrm{E}-07$ & $9.87 E-10$ & $8.74 \mathrm{E}-10$ & $2.65 \mathrm{E}-10$ & $6.63 \mathrm{E}-06$ \\
\hline 2330 & $5.21 \mathrm{E}-12$ & $2.47 \mathrm{E}-07$ & 2.75E-06 & $4.52 E-11$ & $4.32 \mathrm{E}-11$ & $1.31 \mathrm{E}-11$ & $2.58 E-05$ \\
\hline $234 U$ & $4.76 \mathrm{E}-06$ & 4.19E-07 & $3.65 E-05$ & $4.11 \mathrm{E}-05$ & $4.63 \mathrm{E}-05$ & $1.41 \mathrm{E}-05$ & $8.30 \mathrm{E}-05$ \\
\hline 2350 & $2.10 \mathrm{E}-07$ & $1.83 \mathrm{E}-08$ & 1.61E-06 & 1.81E-06 & $2.06 \mathrm{E}-06$ & $6.24 \mathrm{E}-07$ & 3.22E-06 \\
\hline $236 \mathrm{U}$ & $4.85 \mathrm{E}-08$ & $5.13 E-09$ & 3.87E-07 & $4.20 \mathrm{E}-07$ & $3.98 \mathrm{E}-07$ & 1.21E-07 & $4.83 \mathrm{E}-06$ \\
\hline $238 \mathrm{U}$ & $4.84 \mathrm{E}-06$ & 4.19E-07 & $3.71 \mathrm{E}-05$ & 4.17E-05 & $4.72 E-05$ & $1.43 \mathrm{E}-05$ & 6.09E-05 \\
\hline $237 \mathrm{~Np}$ & $4.57 \mathrm{E}-08$ & $1.10 \mathrm{E}-06$ & $5.70 \mathrm{E}-07$ & $3.28 \mathrm{E}-08$ & $8.31 \mathrm{E}-08$ & $3.01 \mathrm{E}-09$ & 2.19E-06 \\
\hline $238 \mathrm{Pu}$ & $8.27 \mathrm{E}-06$ & $1.28 \mathrm{E}-07$ & $1.15 \mathrm{E}-05$ & $8.43 E-06$ & 2.17E-06 & $1.28 \mathrm{E}-06$ & $2.44 E-04$ \\
\hline $239 \mathrm{Pu}$ & $1.08 \mathrm{E}-03$ & $9.13 E-06$ & $1.04 \mathrm{E}-03$ & 1.05E-03 & 3.31E-04 & $1.94 \mathrm{E}-04$ & $1.05 \mathrm{E}-02$ \\
\hline 240Pu & $1.03 E-04$ & $1.03 \mathrm{E}-06$ & $1.11 \mathrm{E}-04$ & $1.02 \mathrm{E}-04$ & $2.84 E-05$ & $1.66 \mathrm{E}-05$ & $2.62 E-03$ \\
\hline $241 \mathrm{Pu}$ & $3.53 \mathrm{E}-04$ & $7.42 \mathrm{E}-06$ & 5.98E-04 & $3.70 E-04$ & $8.57 \mathrm{E}-05$ & $5.01 \mathrm{E}-05$ & $1.19 E-02$ \\
\hline $242 \mathrm{Pu}$ & 1.61 E-09 & $3.92 E-11$ & $2.98 \mathrm{E}-09$ & $1.69 \mathrm{E}-09$ & $3.85 \mathrm{E}-10$ & $2.26 \mathrm{E}-10$ & $3.35 E-08$ \\
\hline $241 \mathrm{Am}$ & $2.24 \mathrm{E}-06$ & $3.38 E-05$ & 2.07E-04 & $2.11 \mathrm{E}-04$ & 3.73E-06 & $1.35 \mathrm{E}-07$ & $1.10 E-02$ \\
\hline 243Am & $1.58 E-11$ & $1.12 \mathrm{E}-09$ & $6.91 E-09$ & $1.51 \mathrm{E}-09$ & $2.60 \mathrm{E}-11$ & $9.41 E-13$ & $5.29 \mathrm{E}-08$ \\
\hline $242 \mathrm{Cm}$ & $9.66 \mathrm{E}-09$ & $7.81 \mathrm{E}-08$ & $5.98 \mathrm{E}-07$ & $2.59 \mathrm{E}-06$ & $3.50 \mathrm{E}-08$ & $2.94 E-09$ & $1.96 \mathrm{E}-05$ \\
\hline $243 \mathrm{Cm}$ & $1.98 \mathrm{E}-10$ & $7.16 \mathrm{E}-09$ & $4.65 \mathrm{E}-08$ & $5.33 E-08$ & $7.19 \mathrm{E}-10$ & $6.00 \mathrm{E}-11$ & $3.82 E-07$ \\
\hline $244 \mathrm{Cm}$ & $3.62 \mathrm{E}-10$ & $7.41 E .08$ & $4.64 \mathrm{E}-07$ & $3.59 \mathrm{E}-08$ & $6.15 \mathrm{E}-10$ & $2.23 \mathrm{E}-11$ & $4.81 E-06$ \\
\hline
\end{tabular}




\section{ATTACHMENT 3 OF NOC \\ ESTIMATED INVENTORY AND EMISSIONS FOR 244-TX DRAIN BACK}

(Consisting of 2 pages, including cover) 


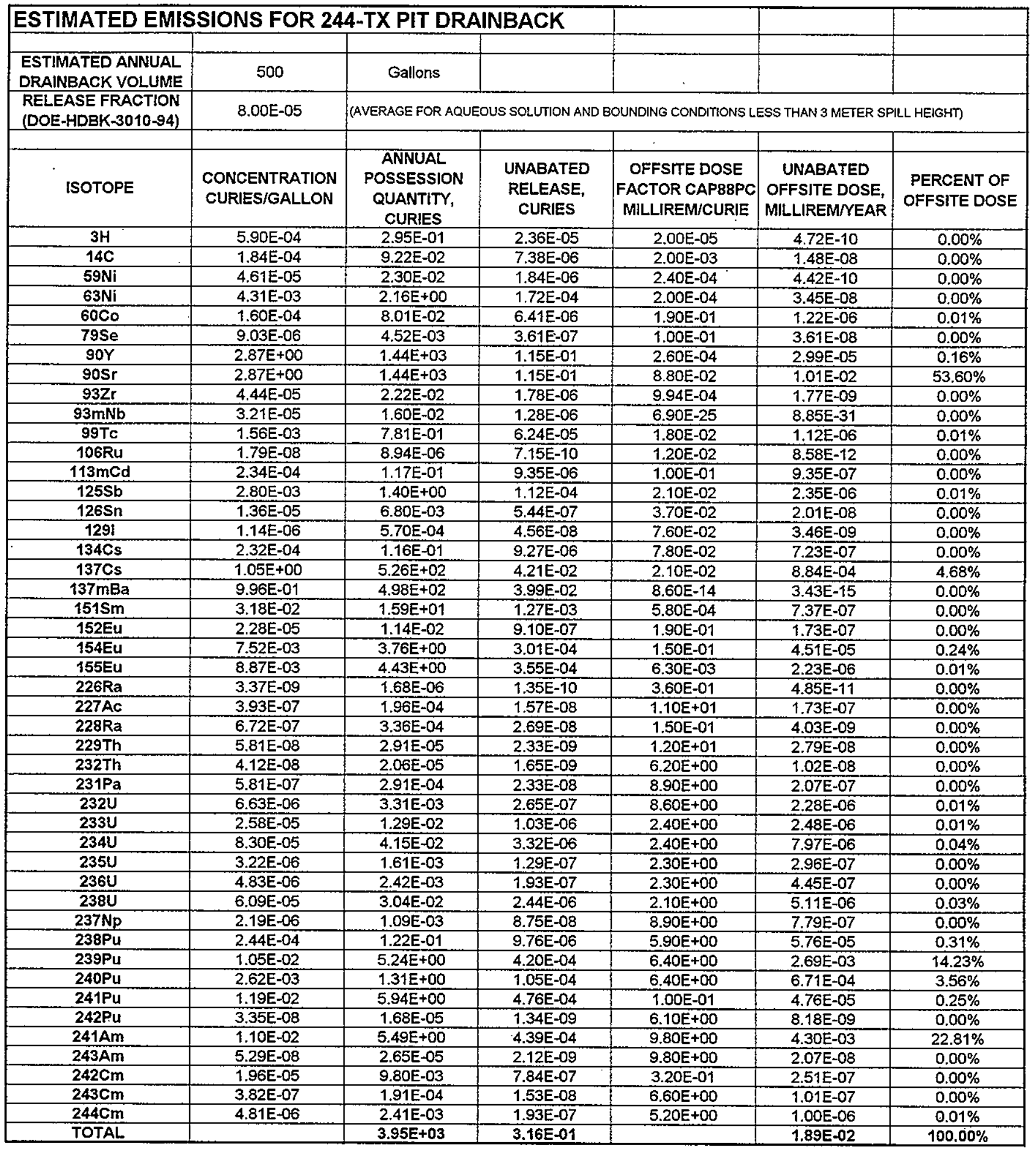




\section{ATTACHMENT 4 OF NOC}

\section{ESTIMATED INVENTORY AND EMISSIONS FOR REMAINING 10 GALLONS}

(Consisting of 2 pages, including cover) 


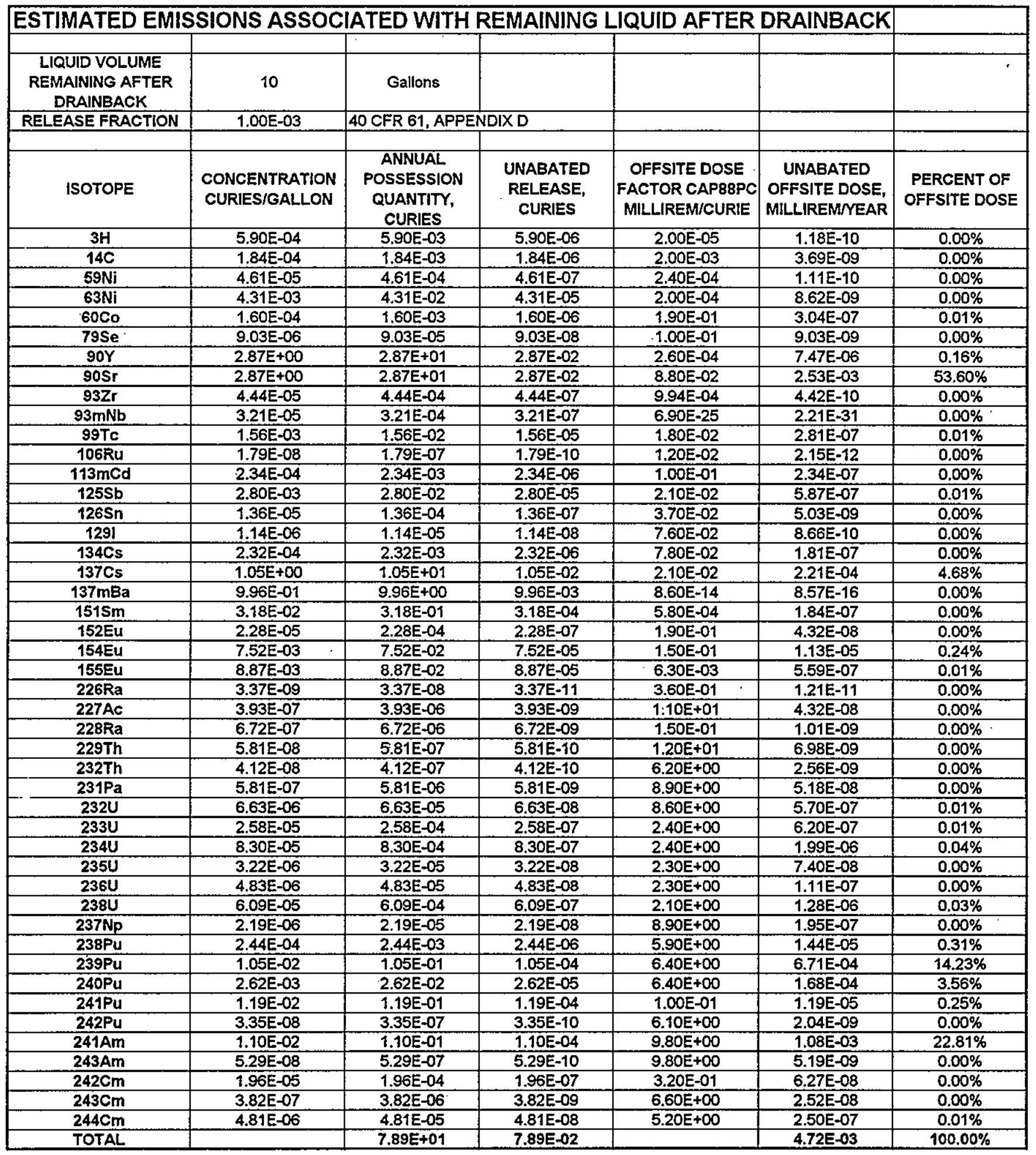


TOTAL ESTIMATED INVENTORY (ANNUAL POSSESSION QUANTITY) AND EMISSIONS

(Consisting of 2 pages, including cover) 


\section{SUMMARY OF OVERALL EMISSIONS FOR 244-TX PIT WORK}

\begin{tabular}{|c|c|c|c|c|}
\hline ISOTOPE & $\begin{array}{l}\text { ANNUAL } \\
\text { POSSESSION } \\
\text { QUANTITY, } \\
\text { CURIES }\end{array}$ & $\begin{array}{l}\text { UNABATED } \\
\text { RELEASE, } \\
\text { CURIES }\end{array}$ & $\begin{array}{l}\text { UNABATED } \\
\text { OFFSITE DOSE, } \\
\text { MILLIREMIYEAR }\end{array}$ & $\begin{array}{l}\text { PERCENT OF } \\
\text { OFFSITE DOSE }\end{array}$ \\
\hline $3 \mathrm{H}$ & $3.01 \mathrm{E}-01$ & $2.95 \mathrm{E}-05$ & $5.90 \mathrm{E}-10$ & $0.00 \%$ \\
\hline $14 \mathrm{C}$ & $9.40 \mathrm{E}-02$ & $9.22 \mathrm{E}-06$ & $1.84 \mathrm{E}-08$ & $0.00 \%$ \\
\hline $59 \mathrm{Ni}$ & $2.35 \mathrm{E}-02$ & $2.30 E-06$ & $5.53 E-10$ & $0.00 \%$ \\
\hline $63 \mathrm{Ni}$ & $2.20 \mathrm{E}+00$ & $2.16 E-04$ & 4.31E-08 & $0.00 \%$ \\
\hline $60 \mathrm{Co}$ & $8.17 E-02$ & 8.01E-06 & $1.52 \mathrm{E}-06$ & $0.01 \%$ \\
\hline $79 \mathrm{Se}$ & $4.61 \mathrm{E}-03$ & $4.52 \mathrm{E}-07$ & $4.52 \mathrm{E}-08$ & $0.00 \%$ \\
\hline $90 Y$ & $1.47 \mathrm{E}+03$ & 1.44E-01 & $3.74 \mathrm{E}-05$ & $0.16 \%$ \\
\hline $90 \mathrm{Sr}$ & $1.47 E+03$ & $1.44 \mathrm{E}-01$ & $1.26 \mathrm{E}-02$ & $53.60 \%$ \\
\hline $93 \mathrm{Zr}$ & $2.27 \mathrm{E}-02$ & $2.22 \mathrm{E}-06$ & $2.21 \mathrm{E}-09$ & $0.00 \%$ \\
\hline $93 \mathrm{mNb}$ & $1.64 \mathrm{E}-02$ & $1.60 \mathrm{E}-06$ & $1.11 E-30$ & $0.00 \%$ \\
\hline 99Tc & $7.96 \mathrm{E}-01$ & $7.81 \mathrm{E}-05$ & $1.41 \mathrm{E}-06$ & $0.01 \%$ \\
\hline 106Ru & $9.12 E-06$ & $8.94 \mathrm{E}-10$ & $1.07 \mathrm{E}-11$ & $0.00 \%$ \\
\hline $113 \mathrm{mCd}$ & 1.19E-01 & $1.17 \mathrm{E}-05$ & $1.17 \mathrm{E}-06$ & $0.00 \%$ \\
\hline $125 \mathrm{Sb}$ & $1.43 \mathrm{E}+00$ & $1.40 \mathrm{E}-04$ & $2.94 \mathrm{E}-06$ & $0.01 \%$ \\
\hline $1265 n$ & $6.93 \mathrm{E}-03$ & $6.80 \mathrm{E}-07$ & 2.51E-08 & $0.00 \%$ \\
\hline 1291 & $5.81 \mathrm{E}-04$ & 5.70E-08 & 4.33E-09 & $0.00 \%$ \\
\hline 134Cs & $1.18 \mathrm{E}-01$ & $1.16 \mathrm{E}-05$ & 9.03E-07 & $0.00 \%$ \\
\hline $137 \mathrm{Cs}$ & $5.36 \mathrm{E}+02$ & $5.26 \mathrm{E}-02$ & $1.10 \mathrm{E}-03$ & $4.68 \%$ \\
\hline $137 \mathrm{mBa}$ & $5.08 \mathrm{E}+02$ & $4.98 \mathrm{E}-02$ & $4.28 \mathrm{E}-15$ & $0.00 \%$ \\
\hline $151 \mathrm{sm}$ & $1.62 E+01$ & $1.59 \mathrm{E}-03$ & $9.21 \mathrm{E}-07$ & $0.00 \%$ \\
\hline 152Eu & 1.16E-02 & $1.14 E-06$ & $2.16 E-07$ & $0.00 \%$ \\
\hline 154EU & $3.84 \mathrm{E}+00$ & $3.76 \mathrm{E}-04$ & 5.64 E-05 & $0.24 \%$ \\
\hline 155EU & $4.52 \mathrm{E}+00$ & 4.43E-04 & $2.79 \mathrm{E}-06$ & $0.01 \%$ \\
\hline 226Ra & 1.72E-06 & $1.68 \mathrm{E}-10$ & $6.06 \mathrm{E}-11$ & $0.00 \%$ \\
\hline $227 A c$ & $2.00 \mathrm{E}-04$ & $1.96 \mathrm{E}-08$ & $2.16 \mathrm{E}-07$ & $0.00 \%$ \\
\hline 228Ra & $3.43 E-04$ & $3.36 \mathrm{E}-08$ & 5.04E-09 & $0.00 \%$ \\
\hline 229Th & 2.97E-05 & 2.91E-09 & $3.49 E-08$ & $0.00 \%$ \\
\hline 232Th & $2.10 \mathrm{E}-05$ & $2.06 \mathrm{E}-09$ & $1.28 \mathrm{E}-08$ & $0.00 \%$ \\
\hline $231 \mathrm{~Pa}$ & 2.97E-04 & $2.91 \mathrm{E}-08$ & 2.59E-07 & $0.00 \%$ \\
\hline $232 U$ & $3.38 \mathrm{E}-03$ & $3.31 \mathrm{E}-07$ & $2.85 E-06$ & $0.01 \%$ \\
\hline $233 U$ & 1.32E-02 & 1.29E-06 & $3.10 \mathrm{E}-06$ & $0.01 \%$ \\
\hline $234 U$ & 4.24E-02 & $4.15 \mathrm{E}-06$ & 9.96E-06 & $0.04 \%$ \\
\hline $235 \mathrm{U}$ & 1.64E-03 & 1.61E-07 & $3.70 \mathrm{E}-07$ & $0.00 \%$ \\
\hline $236 \mathrm{U}$ & 2.47E-03 & 2.42E-07 & 5.56E-07 & $0.00 \%$ \\
\hline $238 \mathrm{U}$ & $3.11 \mathrm{E}-02$ & $3.04 \mathrm{E}-06$ & 6.39E-06 & $0.03 \%$ \\
\hline $237 N p$ & $1.12 \mathrm{E}-03$ & 1.09E-07 & $9.73 E-07$ & $0.00 \%$ \\
\hline 238Pu & 1.25E-01 & 1.22E-05 & $7.20 \mathrm{E}-05$ & $0.31 \%$ \\
\hline $239 \mathrm{Pu}$ & $5.35 E+00$ & 5.24E-04 & 3.36E-03 & $14.23 \%$ \\
\hline $240 \mathrm{Pu}$ & $1.34 \mathrm{E}+00$ & 1.31E-04 & 8.39E-04 & $3.56 \%$ \\
\hline 241Pu & $6.06 \mathrm{E}+00$ & $5.94 \mathrm{E}-04$ & $5.94 \mathrm{E}-05$ & $0.25 \%$ \\
\hline 242Pu & 1.71E-05 & 1.68E-09 & $1.02 \mathrm{E}-08$ & $0.00 \%$ \\
\hline 241Am & $5.60 \mathrm{E}+00$ & $5.49 \mathrm{E}-04$ & $5.38 \mathrm{E}-03$ & $22.81 \%$ \\
\hline 243Am & $2.70 \mathrm{E}-05$ & $2.65 E-09$ & $2.59 \mathrm{E}-08$ & $0.00 \%$ \\
\hline $242 \mathrm{Cm}$ & 9.99E-03 & $9.80 \mathrm{E}-07$ & $3.14 \mathrm{E}-07$ & $0.00 \%$ \\
\hline $243 \mathrm{Cm}$ & $1.95 \mathrm{E}-04$ & $1.91 \mathrm{E}-08$ & $1.26 \mathrm{E}-07$ & $0.00 \%$ \\
\hline $244 \mathrm{Cm}$ & $2.45 \mathrm{E}-03$ & $2.41 \mathrm{E}-07$ & $1.25 \mathrm{E}-06$ & $0.01 \%$ \\
\hline TOTAL & $4.02 E+03$ & $3.95 E-01$ & $2.36 \mathrm{E}-02$ & $100.00 \%$ \\
\hline
\end{tabular}




\section{DISTRIBUTION}

J. Leitch

United States Environmental Protection Agency

Region 10

1200 Sixth Avenue

Seattle, Washington, 98101

A. W. Conklin

Washington State Department of Health

7171 Cleanwater Lane, Building 5

Olympia, Washington 98504

R. S. Acselrod

Washington State Department of Health

PMB 385

2839 W. Kennewick, Avenue

Kennewick, Washington 99336

J. W. Schmidt

Washington State Department of Health

PMB 385

2839 W. Kennewick, Avenue

Kennewick, Washington 99336

J. Wilkinson

Confederated Tribes of the Umatilla Indian Nation

P. O. Box 638

Pendleton, Oregon 97801

D. Powaukee

Nez Perce Tribe

P. O. Box 365

Lapwai, Idaho 93540

R. Jim, Manager

Environmental Restoration/Waste Management Program Yakima Indian Nation

P. O. Box 151

Toppenish, Washington 98948 


\section{DISTRIBUTION}

MSIN

U.S. Department of Energy, Richland Operations Office

D. W. Bowser

A2-22

S. E. Clarke

A5-15

D. M. Collado

A5-18

A. V. Ingle

A5-15

D. E. Olson

$\mathrm{H} 0-12$

J. E. Peschong

S7-51

J. A. Poppiti

S7-54

J. E. Rasmussen

A5-15

H. M. Rodriguez

A5-15

R. M. Yasek

S7-54

Public Reading Room

$\mathrm{H} 2-53$

Fluor Daniel Hanford, Inc.

W. D. Adair

H6-21

J. A. Bates

H6-23

L. E. Borneman

A3-03

T. B. Veneziano

S7-40

J. D. Williams

H6-06

Lockheed Martin Hanford Corp.

D. J. Carrell

Rl-51

D. E. Clark

Rl-51

J. A. Crawford

S7-20

B. G. Erlandson

Rl-5I

R. E. Larson

T4-07

C. C. Haass

R2-89

M. S. Harrington

R2-88

T. L. Hissong

S7-20

M. R. Koch

S7-24

D. G. Larsen

T4-08

P. C. Miller

RI-51

D. P. Niebuhr

T4-01

D. J. Saueressig

S7-20

D. L. Sparks

S5-07

Pacific Northwest National Laboratory

Hanford Technical Library

P8-55

Waste Management Federal Services Hanford, Inc.

B. L. Curn

H6-36

L. P. Diediker

H6-36

E. M. Greager

H6-36

J. S. Hill

H6-25

J. J. Luke

H6-25 
Lockheed Martin Services, Inc. Central Files

B1-07

DPC

H6-08

EDMC (2)

H6-08 